5. Старилов Ю.Н. Курс общего административного права : в 3 т. Москва : НОРМА, 2002. T. $1.728 \mathrm{c}$.

6. Бельський К.С. Выдающийся русский ученый-полицеист В.Н. Лешков. Государство и право. 1966. № 11. С. 127-136.

7. Антологія української юридичної думки : у 6 т. / редкол. : Ю.С. Шемшученко (голова) та ін. ; упоряд. : Ю.І. Римаренко, В.Б. Авер'янов, І.Б. Усенко ; відп. ред. Ю.І. Римаренко, В.Б. Авер'янов. Київ : Вид. дім «Юрид. книга», 2003. Т. 5 : Поліцейське та адміністративне право. 600 с.

8. Петров Є.В. Феноменологія адміністративно-господарського права : монографія. Харків : Диса плюс, 2012. 392 с.

9. Ивановский В.В. Учебник административного права (Полицейское право. Право внутреннего управления). 4-е изд. Казань, 1911. 516 с.

10. Миколенко O.I. Місце адміністративного процедурного права в системі юридичних знань та системі права України : дис. ... докт. юрид. наук : 12.00.07. Запоріжжя, 2011. 444 с.

11. Адміністративна юстиція. Адміністративне судочинство : навчальний посібник / Т.О. Коломоєць, Г.Ю. Гулєвська, Р.В. Сінєльнік, І.О. Сквірський ; за заг. ред. Т.О. Коломоєць, Г.Ю. Гулєвської. Київ : Істина, 2007. 152 с.

12. Макарчук В.С. Основи римського приватного права : навчально-методичний посібник. Київ : Атіка, 2003. 256 с.

13. Тарасов И.Т. Учение об акционерных компаниях. Москва : Статут, 2000. 666 с.

14. Ионова Ж.А. Правовые проблемы государственной регистрации и лицензирования предпринимательства : дисс. ... канд. юрид. наук : 12.00.14. Москва, 1997. 172 с.

15. Про підприємництво : Закон України від 7 лютого 1991 р. № 698-ХІІ (утратив чинність). URL : https://zakon.rada.gov.ua/laws/show/698-12\#Text.

16. Про державну реєстрацію юридичних осіб, фізичних осіб-підприємців та громадських формувань : Закон України від 15 травня 2003 р. № 755-IV. URL: https://zakon.rada.gov.ua/laws/ show/755-15\#Text.

УДК 342.9

DOI https://doi.org/10.32844/2618-1258.2020.6-1.28

КОНОНЕЦЬ В.П.

\author{
ПРОБЛЕМНІ АСПЕКТИ ПРИМУСОВОГО ВИКОНАННЯ \\ РІШЕННЯ ДЕРЖАВНИМ ВИКОНАВЦЕМ У МЕЖАХ СПРАВ \\ ПРО АДМІНІСТРАТИВНІ ПРАВОПОРУШЕННЯ
}

\title{
PROBLEMATIC ASPECTS OF ENFORCEMENT OF THE DECISION BY THE STATE EXECUTOR IN CASES OF ADMINISTRATIVE OFFENSES
}

Актуальність статті полягає в тому, що виконавче провадження є останнім етапом провадження, що полягає в примусовому виконанні судових рішень, рішень інших органів, посадових осіб, які головним чином уповноважені розглядати справи про адміністративні правопорушення. Ця крайня ланка правозастосовної процедури $є$ не менш важливою в порівнянні з іншими стадіями провадження у справах про адміністративні правопорушення, тому що вона є основним гарантом виховання як громадян (загальна превенція), так й осіб, визнаних винними в учиненні адміністративного правопорушення (спеціальна превенція) у дусі точного та неухильного додержання Конституції та законів України. Крім того, ця сходинка також забезпечує реалізацію фундаментального принципу виконавчого провадження - обов'язковість виконання рішення, без якого є ілюзорним процес

( КОНОНЕЦЬ В.П. - кандидат юридичних наук, доцент, доцент кафедри адміністративного права, процесу та адміністративної діяльності (Дніпропетровський державний університет внутрішніх справ) 
виховання. Мета статті полягає в тому, щоб виправити колізійні особливості в правовому вимірі сфери забезпечення примусового виконання рішення, що не дає змогу посадовим особам органів державної виконавчої служби здійснювати належним чином свої повноваження. 3'ясовано, що офіційно судову практику не визнають джерелами права в силу свого рекомендаційного характеру, але водночас вона $\epsilon$ необхідним допоміжним підгрунтям для прийняття судами процесуальних рішень під час розгляду справи, посилаючись на судові рішення минулих років. Проаналізуємо Постанову Верховного Суду щодо вирішення питання про відкриття виконавцем виконавчого провадження в разі відсутності у виконавчому документі ідентифікаційного коду, аби заринути в суть цієї проблеми. Визначено, що принцип оперативності означає швидке та правильне виконання поставлених завдань, а економність сил і засобів - це мінімум часових витрат і витрат іншого характеру, у тому числі матеріальних, для державного виконавця під час провадження примусового виконання рішення. Постає необхідність усунення цих законодавчих колізій для спрощення порядку доступу до даних, які не є персональними, а саме ідентифікаційного коду платника податків. Це можна досягти тільки шляхом унесення законодавцем правильних змін до закону й інших нормативно-правових актів.

Ключові слова: адміністративне стягнення, громадянин, санкція, виконавчий документ.

The relevance of the article is that enforcement proceedings are the last stage of the proceedings, which consists in the enforcement of court decisions, decisions of other bodies, officials, who are mainly authorized to consider cases of administrative offenses. This extreme link of law enforcement procedure is no less important in comparison with other stages of proceedings in cases of administrative offenses, because it is the main guarantor of education of both citizens (general prevention) and persons found guilty of administrative offenses (special prevention) in the spirit of strict and strict observance of the Constitution and laws of Ukraine. In addition, this step also ensures the implementation of the fundamental principle of enforcement proceedings - the obligation to implement the decision, without which the process of education is illusory. The purpose of the article is to correct the conflicting features in the legal dimension of the enforcement of the decision, which does not allow officials of the state executive service to exercise their powers properly. It was found that case law is not officially recognized as a source of law due to its recommendatory nature, but at the same time it is a necessary supporting basis for courts to make procedural decisions during the case, referring to court decisions of previous years. Let's analyze the decision of the Supreme Court to resolve the issue of initiating enforcement proceedings by the executor in the absence of an identification code in the executive document, in order to delve into the essence of this problem. It is determined that the principle of efficiency means fast and correct execution of tasks, and economy of forces and means is a minimum of time and other costs, including material, for the state executor during the enforcement of the decision. There is a need to eliminate the data of legislative conflicts to simplify the procedure for access to non-personal data, namely - the identification code of the taxpayer. This can be achieved only by the legislator making the right changes to the law and other regulations.

Key words: administrative penalty, citizen, sanction, executive document.

Вступ. Виконавче провадження є останнім етапом провадження, що полягає в примусовому виконанні судових рішень, рішень інших органів, посадових осіб, які головним чином уповноважені розглядати справи про адміністративні правопорушення. Ця крайня ланка правозастосовної процедури $є$ не менш важливою в порівнянні з іншими стадіями провадження у справах про адміністративні правопорушення, тому що вона є основним гарантом виховання як громадян (загальна превенція), так й осіб, визнаних винними в учиненні адміністративного правопорушення (спеціальна превенція) у дусі точного та неухильного додержання Конституції та законів України. Крім того, ця сходинка також забезпечує реалізацію фундаментального принципу виконавчого провадження - обов'язковість виконання рішення, без якого $є$ ілюзорним процес виховання. Наприклад, у виконавчому документі відсутні необхідні дані про особу боржника, 
що дасть змогу суб'єкту владних повноважень оперативно, економічно й точно примушувати його до примусового виконання рішення на користь стягувача, дотримуючись установлених законодавством строків. До того ж якщо у виконавчому документі відсутній ідентифікаційний код платника податків або паспортні дані, то виконавчий документ підлягає поверненню стягувачу. Вирішення цього казусу дасть змогу забезпечити належне дотримання принципу обов'язковості виконання рішень і головне завдання Кодексу України про адміністративні правопорушення (далі - КУПАП) - виховання та невідворотність покарання.

Постановка завдання. Мета статті - виправити колізійні особливості в правовому вимірі сфери забезпечення примусового виконання рішення, що не дає змоги посадовим особам органів державної виконавчої служби здійснювати належним чином свої повноваження.

Завдання - проаналізувати та розтлумачити чинні норми КУпАП і законів, що регулюють питання виконавчого провадження.

Результати дослідження. Сьогодні Національна поліція України для забезпечення виконання покладених на неї завдань уживає чимало заходів, які входять до іії компетенції, на неї покладено головне завдання щодо забезпечення й охорони прав і свобод людини. Так, у п. 8 ст. 23 Закону України «Про Національну поліцію» поліція приймає рішення про застосування адміністративних стягнень за вчинення адміністративних правопорушень, вичерпний перелік яких наведений у ст. 222 КУпАП [1]. У таких випадках уповноважені працівники поліції, відповідно до ст. ст. 258, 283 КУпАП, виносять постанову про накладення штрафу [2]. Крім того, поліція забезпечує та здійснює контроль над примусовим виконанням рішення. Як згадувалося вище, ці передбачені законом дії є невід'ємною частиною виховання особи та здійснення поліцією загальної та спеціальної превенції.

Згідно 3 ч. 1 ст. 307 КУПАП, штраф має бути сплачений порушником не пізніше п’ятнадцяти діб з дня вручення йому постанови у справі про адміністративне правопорушення. Однак, звертаючи увагу на практику, приблизно кожна третя особа, яка була зобов'язана сплатити штраф, не вкладається з різних причин у визначений законодавством строк виконання стягнення, проте найпоширеніший мотив такої поведінки закладається саме в фундаменті правового нігілізму. Беззаперечно, це є проблемою всього суспільства, усієї держави. Так, згідно 3 ч. 1 ст. 308 КУПАП, якщо порушник у п'ятнадцятиденний строк не сплачує штраф, то уповноважена посадова особа органу Національної поліції відправляє постанову разом із виконавчим документом - заявою до органу державної виконавчої служби (державного виконавця). У цьому разі порушник зобов'язаний сплатити подвійний розмір штрафу відповідно до призначеної кількості неоподаткованих мінімумів доходів громадян у межах санкції статті або частини статті, яка регламентує відповідальність за суспільно шкідливі діяння (дію чи бездіяльність), учинені особою, а також витрати на облік зазначених правопорушень [3, с. 292-293]. Тут уже існують свої процесуальні складнощі, які ми будемо обговорювати в дослідженні, вирішення котрих будуть сприяти досягненню мети роботи.

Відповідно до ст. 3 Закону України «Про звернення громадян», заява - це звернення громадян до державних органів, закладів, установ, організацій з метою реалізації закріплених у Конституції та законах свої прав, свобод і законних інтересів, у тому числі повідомлення вказаних державних суб' єктів про порушення ними чинного законодавства, а також акцентування на недоліки в їхній діяльності. Клопотанням розглядається як письмове звернення до уповноважених органів державної влади про визнання за собою чи за іншими особами спеціального статусу, прав чи свобод [4]. Виходить, що виконавчий документ (заява) - це і $\epsilon$, по суті, клопотанням, яке передбачено вказаним законом, бо в нашому випадку поліцейський-стягувач шляхом надання постанови та заяви державному виконавцю звертається до останнього про закріплення за боржником обов'язку - примусово виконати рішення про сплату штрафу.

Ведучи мову про виконавче провадження у справах про адміністративні правопорушення, поліцейські в постанові не зазначають ідентифікаційний код платника податків, через що державний виконавець або повертає виконавчий документ поліцейському-стягувачу, або здійснює запит органам фіскальної служби щодо надання йому ідентифікаційного коду. Це пояснюється тим, що поліцейський не вимагає пред’явлення коду при складанні постанови або ж особа, щодо якої виноситься постанова, відмовляється давати код, мотивуючи це тим, що це порушує ії основоположне право на невтручання в особисте життя, яке закріплене в ст. 32 Конституції України [5]. До того ж у ч. 2 ст. 283 КУпАП серед обов'язкових реквізитів постанови по справі про адміністративне правопорушення такий реквізит, як ідентифікаційний код платника податків, відсутній. 
Державна фіскальна служба визначає ідентифікаційний код як особистий індивідуальний десятизначний номер для обліку у фіскальних органах для сплати податків та інших обов'язкових платежів [6]. Ідентифікаційний номер складається з десяти цифр. Перші п'ять цифр кодують дату народження власника номера, як правило, це п'ятизначне число являє собою кількість днів від 31 грудня 1899 року до дати народження людини. Однак, якщо однакову дату народження мають понад 5000 чоловіків (або 5000 жінок), то в деяких 3 них перші п’ять цифр будуть іншими. Наприклад, для дати народження 1 січня 1947 реєстраційний номер може починатися як 3 цифри «1», так і з цифри «8». Наступні 4 цифри (частково включаючи передостанню) позначають порядковий номер людини, яка народилася в цей день. У передостанній цифрі закодований стать власника: якщо цифра непарна, стать - чоловіча, а якщо парна - жіночий [7].

Згідно зі ст. 2 Закону України «Про персональні дані», персональними даними визнаються відомості чи сукупність відомостей про фізичну особу, яка ідентифікована або може бути конкретно ідентифікована [8]. Про ідентифікаційний код ні в цьому Законі, ні в КУпАП, ні в інших нормативно-правових актах не згадується. Уважаємо за правильне звернути увагу на те, що існує багато реальних випадків, коли шахраї, які мають «на руках» ідентифікаційний код інших осіб, використовують їхні дані для незаконних махінацій. Таке твердження щільно поєднане з рівнем довіри населення до органів поліції. Зараз, на жаль, рівень довіри українського суспільства до охоронців правопорядку та законності загалом має низький відсоток, що є проявом соціальної аномії. Отже, особа, стосовно якої винесена постанова у справі про адміністративне правопорушення, має повне право відмовитися надавати код працівнику поліції в одному з таких випадків або їх сукупності: до закону;

1) ідентифікаційний код платника податків не є персональними даними особи відповідно

2) у ч. 2 ст. 283 КУпАП відсутній такий обов'язковий реквізит, як ідентифікаційний код платника податків;

3) наявність численних життєвих випадків щодо шахрайства на основі незаконних махінацій з ідентифікаційним кодом особи, що може будуватися на низькому рівні довіри населення до поліції.

Заява як виконавчий документ, форма якої закріплена в Інструкції з оформлення поліцейськими матеріалів про адміністративні правопорушення у сфері забезпечення безпеки дорожнього руху, зареєстровані не в автоматичному режиму режимі, затвердженій Наказом МВС від 07.11.2015 № 1395, не містить реквізиту «реєстраційний номер облікової картки платника податків», тобто коду особи, яка за законодавством зобов'язана виконати рішення [9].

Офіційно судову практику не визнають джерелами права в силу свого рекомендаційного характеру, але водночас вона $є$ необхідним допоміжним підгрунтям для прийняття судами процесуальних рішень під час розгляду справи, посилаючись на судові рішення минулих років. Проаналізуємо Постанову Верховного Суду щодо вирішення питання про відкриття виконавцем виконавчого провадження в разі відсутності у виконавчому документі ідентифікаційного коду, аби заринути в суть цієї проблеми.

24 грудня 2018 року в м. Києві Верховний Суд у складі колегії суддів Першої судової палати Касаційного цивільного суду: С.Ф. Хопти (суддя-доповідач), Є.В. Синельникова, В.В. Шиповича, учасники справи: заявник (стягувач) - приватне акціонерне товариство «Страхова компанія «Українська страхова група», суб'скт оскарження - державний виконавець Міжрайонного відділу державної виконавчої служби по Холодногірському та Новобаварському районах м. Харкова Головного територіального управління юстиції встановив: у травні 2018 року приватне акціонерне товариство «Страхова компанія «Українська страхова група» (далі - ПрАТ «СК «Українська страхова група») звернулося до суду зі скаргою на дії державного виконавця Міжрайонного відділу державної виконавчої служби по Холодногірському та Новобаварському районах м. Харкова Головного територіального управління юстиції у Харківській області Ю.В. Грар (далі - Міжрайонний ВДВС по Холодногірському та Новобаварському районах м. Харкова Головного ТУЮ у Харківській області) про визнання дій незаконними, скасування прийнятих рішень і зобов'язання вчинити певні дії. ПрАТ «СК «Українська страхова група» просило суд: визнати неправомірними дії держаного виконавця щодо винесення повідомлення про повернення виконавчого документа стягувачу без прийняття до виконання від 11 квітня 2018 року; скасувати повідомлення про повернення виконавчого документа стягувачу; зобов'язати державного виконавця винести постанову про відкриття виконавчого провадження. Скарга мотивована тим, що 13 лютого 2018 року Жовтневим районним судом м. Харкова ви- 
дано виконавчий лист на примусове виконання рішення про стягнення з ОСОБА_1 на користь ПрАТ «СК «Українська страхова група» суми страхового відшкодування в розмірі 21893,77 грн та 1 600,00 грн судового збору.

Ухвала апеляційного суду мотивована тим, що відсутність у виконавчому документі реєстраційного номера облікової картки платника податків боржника не є безумовною підставою для повернення виконавчого документа, а тому, як уважав суд першої інстанції, дії державного виконавця порушують права стягувача та є такими, що не відповідають вимогам закону.

У касаційній скарзі, поданій у січні 2019 року до Верховного Суду, Міжрайонний ВДВС по Холодногірському та Новобаварському районах м. Харкова Головного ТУЮ в Харківській області, посилаючись на неправильне застосування норм матеріального права й порушення норм процесуального права, просив скасувати судові рішення судів першої та апеляційної інстанцій та ухвалити нове судове рішення, яким відмовити в задоволенні скарги ПрАТ «СК «Українська страхова група».

У статті 4 Закону України «Про виконавче провадження» в переліку обов'язкових реквізитів виконавчого документа, тобто згаданої заяви, присутній реєстраційний номер облікової картки платника податків. У положеннях ч. 4 цієї ж статті вказано, що виконавчий документ повертається поліцейському-стягувачу, якщо він не відповідає вимогам, передбаченим цією статтею. Якщо ж ідентифікаційний код відсутній, то такий виконавчий документ повертається поліцейському-стягувачу, а також сплачений ним авансний внесок.

Пунктом 6 ч. 1 ст. 26 Закону встановлено, що в разі невідповідності змісту виконавчого листа вимогам ст. 18 державний виконавець відмовляє у відкритті виконавчого провадження. Разом із тим, відповідно до п. 3 ч. 3 ст. 11 Закону, державний виконавець при здійсненні виконавчого провадження має право з метою захисту інтересів стягувача одержувати безоплатно від органів, установ, організацій, посадових осіб, сторін та учасників виконавчого провадження необхідні для проведення виконавчих дій пояснення, довідки й іншу інформацію, у тому числі й конфіденційну. Також, відповідно до ч. 3 ст. 18 цього ж Закону, державний виконавець має право безперешкодно та безоплатно отримати доступ до інформації про особу, його рахунки й інші дані, які наявні в органів державної влади, закладів, установ, фізичних, юридичних осіб тощо. Тому державному виконавцю ніщо не заважає звернутися до фіскальних органів і витребувати ідентифікаційний код особи, яка, відповідно до закону, зобов'язана примусово виконати рішення.

Керуючись ст. ст. 400, 401, 416 Цивільного процесуального кодексу України, Верховний Суд у складі колегії суддів Першої судової палати Касаційного цивільного суду постановив: Касаційну скаргу Міжрайонного відділу державної виконавчої служби по Холодногірському та Новобаварському районах м. Харкова Головного територіального управління юстиції у Харківській області залишити без задоволення. Ухвалу Жовтневого районного суду м. Харкова від 15 серпня 2018 року та постанову Харківського апеляційного суду від 26 листопада 2018 року залишити без змін. Постанова суду касаційної інстанції набирає законної сили з моменту іії прийняття, $є$ остаточною та оскарженню не підлягає [10].

Очевидно, що заявник-стягувач у цьому випадку відсилається на норми ст. 18 Закону, де вказано, що виконавець може самостійно безперешкодно й безоплатно отримати ідентифікаційний код. Із цих мотивів стягувач не вказує код боржника у виконавчому документі, тим самим покладаючи з'ясування ідентифікаційного номеру на виконавця. Але, на нашу думку, Верховний Суд дійшов правильного висновку: він визнав дії виконавця такими, що будуються на чинному законодавстві. Суд у цьому випадку чітко розмежовує імперативний характер положень ст. 4 Закону, де, нагадаємо, указано, що реєстраційний номер облікової картки платника податків повинен бути у виконавчому документі обов'язково наявним, і про диспозитивний характер змісту ч. 3 ст. 18 Закону [11]. Із теорії права відомо, що якщо виникає конфлікт між застосуванням імперативної та диспозитивної норми, то безумовне привілеювання має імперативна норма закону.

Тепер подивимося на цю ситуацію трохи з іншого кута зору: виконавець не повертає стягувачу виконавчий документ назад через відсутність у ньому обов'язкового реквізиту, а відкриває виконавче провадження. Тут ми звертаємо увагу на обставини, які будуть утруднювати або пригальмовувати доступ до цих відомостей і найголовніша 3 них - складна процедура отримання ідентифікаційного коду й тим самим сплив строків виконавчого провадження. У гіршому випадку особа, яка зобов'язана примусово виконати рішення, може змінити місце проживання або перебування, виїхати до іншого міста, району, області тощо. Саме тому дуже важливо для державних виконавців дотримуватися таких принципів їхньої діяльності: оперативності, економності сил і засобів. Принцип оперативності означає швидке та правильне виконання поставлених завдань, а 
економність сил і засобів - це мінімум часових витрат і витрат іншого характеру, у тому числі матеріальних, для державного виконавця під час провадження примусового виконання рішення. Постає необхідність усунення цих законодавчих колізій для спрощення порядку доступу до даних, які не $є$ персональними, а саме ідентифікаційного коду платника податків. Це можна досягти тільки шляхом унесення законодавцем правильних змін до закону й інших нормативно-правових актів.

Стаття 188-13 КУПАП установлює відповідальність особи, яка, відповідно до закону, зобов'язана примусово виконати рішення уповноважених органів за невиконання законних вимог державного виконавця тощо. Якщо державному виконавцю поліцейський у заяві не вказав ідентифікаційний код особи для примусового виконання нею рішення про стягнення штрафу, а державному виконавцю державна фіскальна служба або особа, яка підлягає примусовому виконанню рішення, не надає ідентифікаційний код, такі особи не будуть притягатися до відповідальності. Це пояснюється тим, що в диспозиції згаданої статті немає такого нормативного припису, який би зобов'язував указаних суб'єктів виконавчого провадження надавати державному виконавцю ідентифікаційний код.

Висновки. Провівши дослідження, проаналізувавши чинні норми КУпАП і законів, що регулюють питання виконавчого провадження, з метою виправлень колізійних аспектів у правовому вимірі сфери забезпечення примусового виконання рішення, що не дає змогу посадовим особам органів державної виконавчої служби здійснювати належним чином свої повноваження, полегшення їхньої виконавчої діяльності для примусового виконання рішень у справі про адміністративне правопорушення, пропонуємо внести такі зміни до чинного законодавства:

1) до ч. 2 ст. 283 КУПАП додати обов'язковий реквізит до постанови по справі про адміністративне правопорушення «реєстраційний номер облікової картки платника податків особи, стосовно якої розглядається справа» і текст одного з реквізитів з таким текстом:

«відомості про особу, стосовно якої розглядається справа (прізвище ім'я по батькові (за наявності), дата народження, місце народження, місце проживання чи перебування, місце роботи або навчання)»;

2) до диспозиції статті 188-13 КУпАП із таким текстом:

«Невиконання законних вимог державного виконавця, приватного виконавця щодо усунення порушень законодавства про виконавче провадження, несвоєчасне подання або неподання звітів про відрахування із заробітної плати й інших доходів боржника, неподання або подання недостовірних відомостей про доходи й майновий стан боржника, ненадання на вимогу державного виконавця, приватного виконавця реєстраційного номеру облікової картки платника податків, декларації про доходи та майно, що подається відповідно до Закону України «Про виконавче провадження», чи зазначення в такій декларації неправдивих відомостей або неповідомлення про зміну відомостей, які зазначаються в декларації, неповідомлення боржником про зміну місця проживання чи місцезнаходження або місця роботи (отримання доходів), а також неявка без поважних причин за викликом державного виконавця, приватного виконавця».

\section{Список використаних джерел:}

1. Про Національну поліцію : Закон України від 02.07.2015. URL: https://zakon.rada.gov.ua/ laws/show/580-19\#Text (дата звернення: 17.01.2020).

2. Про затвердження Інструкції з оформлення матеріалів про адміністративні правопорушення в органах поліції : Наказ MBC України від 06.11.2015. URL: https://zakon.rada.gov.ua/laws/ show/z1496-15\#Техt (дата звернення: 17.01.2020).

3. Кодекс України про адміністративні правопорушення: чинне законодавство із змінами та допов. на 17 вересня 2020 року: ОФіц. текст. Київ : Алерта, 2020. 322 с.

4. Про звернення громадян : Закон України від 02.10.1996. URL: https://zakon.rada.gov.ua/ laws/show/393/96-\%D0\%B2\%D1\%80\#Text (дата звернення: 01.01.2020).

5. Конституція України. URL: https://zakon.rada.gov.ua/laws/show/254\%D0\%BA/ 96-\%D0\%B2\%D1\%80\#Text (дата звернення: 01.01.2020).

6. Де отримати індивідуальний податковий номер? URL: https://kyivcity.gov.ua/pasport_ svidotstva_ta_dovidky/identyfikatsiinyi_kod/de_otrymaty_identyfikatsiinyi_kod/\#: :text (дата звернення: 26.02.2017).

7. Ідентифікаційний номер фізичної особи. URL: https://ru.wikipedia.org/wiki/ (дата звернення: 01.01.2021).

8. Про захист персональних даних : Закон України від 01.06.2010. URL: https://zakon.rada. gov.ua/laws/show/2297-17\#Text (дата звернення: 20.03.2020). 
9. Про затвердження Інструкції 3 оформлення поліцейськими матеріалів про адміністративні правопорушення у сфері забезпечення безпеки дорожнього руху, зареєстровані не в автоматичному режиму режимі : Наказ MBC України від 07.11.2015 № 1395. URL: https://zakon.rada.gov.ua/laws/show/1404-19\#Tехt (дата звернення: 30.10.2020).

10. Відсутність у виконавчому документі ідентифікаційного коду боржника не є підставою для повернення його без прийняття до виконання (ВС/КЦС у справі від 24 грудня 2020 p. № 639/2561/18-ц). URL: https://protocol.ua/ru/vidsutnist_u_vikonavchomu_dokumenti identifikatsiynogo kodu borgnika ne e pidstavoyu dlya povernennya yogo bez priynyattya do_vikonannya_(vs_ktss_u_uspravi_639_2561_18_ts_vid_24_grudnya_2020_r_)/ (дата звернення: 12.01.2021).

11. Про виконавче провадження : Закон України від 02.06.2016. URL: https://zakon.rada. gov.ua/laws/show/1404-19\#Text (дата звернення: 10.12.2020).

УДК 342.95: 351.743

DOI https://doi.org/10.32844/2618-1258.2020.6-1.29

КОРНІЕНКО Д.М.

\section{ЕЛЕМЕНТИ МЕХАНІЗМУ (ГАРАНТІЇ, ЗАХОДИ, ЗАСОБИ, ФОРМИ ТА МЕТОДИ) АДМІНІСТРАТИВНО-ПРАВОВОГО ЗАБЕЗПЕЧЕННЯ СЛУЖБОВО-БОЙОВОӤ ДІЯЛЬНОСТІ НАЦІОНАЛЬНОЇ ГВАРДІЇ УКРАЇНИ}

\section{ELEMENTS OF THE MECHANISM (GUARANTEES, MEASURES, MEANS, MEANS, FORMS AND METHODS) OF ADMINISTRATIVE AND LEGAL SUPPORT OF SERVICE AND COMBAT ACTIVITY}

У статті до основних елементів адміністративно-правового забезпечення службово-бойової діяльності НГУ віднесено: 1) об'єкт військового керівництва; 2) суб'єкт військового керівника (командира); 3) норми адміністративного права; 4) адміністративно-правові відносини; 5) гарантії, заходи, засоби, форми та методи адміністративно-правового забезпечення. Одними з елементів адміністративно-правового забезпечення службово-бойової діяльності НГУ визнано гарантії, заходи, засоби, форми та методи.

Установлено, що під гарантією діяльності службово-бойової діяльності НГУ варто розуміти закріплені на законодавчому рівні засоби й/або способи забезпечення здійснення службово-бойової діяльності НГУ. Найбільш доречним визнано поділ гарантій адміністративно-правового регулювання службово-бойової діяльності НГУ на загальносоціальні та спеціально-юридичні (нормативно-правові й організаційно-правові).

Зроблено висновок, що формами адміністративно-правового забезпечення службово-бойової діяльності НГУ є зовнішнє вираження однорідних за своїм характером і правовою природою юридичних дій і видання актів, за допомогою яких забезпечується службово-бойова діяльність НГУ. Форми адміністративно-правового забезпечення службово-бойової діяльності НГУ поділено на правові та неправові.

Установлено, що адміністративно-правове забезпечення службово-бойової діяльності НГУ здійснюються універсальними (загальними) методами, такими як переконання, заохочення та примус. Одним із видів примусу є адміністративний примус. Залежно від мети застосування заходи адміністративного примусу поділяються на три види: 1) адміністративно-запобіжні заходи; 2) заходи адміністративного припинення; 3) заходи адміністративної відповідальності. Зроблено

(C) КОРНІСНКО Д.М. - кандидат юридичних наук, доцент, начальник (Київський факультет Національної академії Національної гвардії України) 